\title{
Staging Exchange: Why The Knight of the Burning Pestle Flopped at Blackfriars in 1607
}

Early modern plays in London that didn't make it - hopeful additions to a company's repertory that evidently flopped at the first performance or had a reputedly short run - are receiving renewed interest. Scholars devote much attention to interpreting plays that had a documented popular following, but what is perhaps more revealing of a culture's priorities and mores are its objects of scorn and derision, particularly when these are popular forms of entertainment. Some playwrights, such as John Webster, who had a cantankerous relationship with some of his audiences, expressed their grievances in print. In the introduction to the 1612 published version of The White Devil, Webster identifies a variety of reasons for its failure on stage aside from 'the incapable multitude' whose 'breath' was 'able to poison' its success:

it was acted in so dull a time of winter, presented in so open and black a theatre, that it wanted (that which is the only grace and setting-out of a tragedy) a full and understanding auditory; and that since that time I have noted, most of the people that come to that playhouse resemble those ignorant asses (who, visiting stationers' shops, their use is not to inquire for good books, but new books), I present it to the general view with this confidence:

Nec rhoncos metues maligniorum,

Nec scombris tunicas dabis molestas. ${ }^{1}$

This kind of negative publicity in print reappeared one year later with the first edition of Francis Beaumont's play The Knight of the Burning Pestle. ${ }^{2}$ In this case, however, the apology was in the form of a prefatory letter from the play's publisher, Walter Burre, to 'HIS MANY WAIES ENDEERED FRIEND Maister Robert Keysar', who managed the Blackfriars during the play's fatal debut there in 1607. 3 This letter shares Webster's impatience with an audience ostensibly incapable of appreciating the play's clever wit: 
SIR, this vnfortunate child ... was by his parents (perhaps because hee was so vnlike his brethren) exposed to the wide world, who for want of iudgment, or not vnderstanding the priuy marke of Ironie about it (which shewed it was no ofspriong of any vulgar braine) vtterly reiected it: so that for want of acceptance it was euen ready to give up the Ghost, and was in danger to have bene smothered in perpetuall oblivion, if you (out of your direct ANTIPATHY to ingratitude) had not bene moved both to relieve and cherish it. ${ }^{4}$

Even though surmising the role(s) of early modern audiences is problematic in any analysis, a range of scholars have attempted to use Burre's letter as a window onto Knight and the reasons for its failed first performance. Alexander Leggatt offers several telling insights into the strategies betraying Beaumont's 'experiment' - strategies that he and Lee Bliss contend were 'overtaxing' the audience's expectations. ${ }^{5}$ Leggatt pushes these financial overtones with his keen observation that the play 'demystifies theatre by presenting it as a cash transaction'. ${ }^{6}$ Leggatt's conjecture follows Andrew Gurr's speculation that enough citizens were in the audience to register collective offence at the play's 'elitist satire and genial contempt for citizens' and Michael Shapiro's observation that the play offers no aristocratic characters to appease the audience's fantasy of being in an elite space. ${ }^{7}$ Together these arguments echo Ronald Miller's more abstract perception that Beaumont's 'attack upon contemporary theatrical tastes becomes, in effect, an onslaught upon the epistemology of the stage itself'. ${ }^{8}$ Other approaches focus less on the play in performance and more on what Burre did with it as a printed text: Zachary Lesser, for instance, considers Burre's practice of 'continuous printing' and the political motivations behind verse epistles. ${ }^{\text {? }}$

Sheldon Zitner's important introduction to the play in his Revels Edition (1984) introduces a promising angle to the argument by pointing out an important connection between the play's 'dramatic personae of discomfited ants and triumphant grasshoppers' and Beaumont's delivery of his Grammar Lecture at the Inner Temple several years before the play's first performance at Blackfriars. ${ }^{10}$ Rather than pursuing this connection, Zitner establishes the play's 'indebted ness and ... innovations ... in the wider context of three related lines of seventeenth-century dramaturgy: the prodigal play, the romantic comedy, and the play of citizen adventure. ${ }^{11}$ My essay picks up the abandoned Inns of Court strand of argument and aligns it with Zitner's several key insights - that the play's structure, style, and content made it 'tailormade for the Blackfriars'12 and that its 'tone of acceptance and celebration 
rather than of mockery and rejection'13 works to formulate a momentary illusory community of inclusion that 'the gentlemen seated on the stage will not accept'. ${ }^{14}$ While my own approach to the question of the play's failure is underpinned by many of Zitner's key metatheatrical insights into the play's 'special irony', it also seeks to contemplate the variables on which this irony depends more precisely. While Zitner observes that 'laughter must have an occasion in persons, events, [and] ideas' and that the 'kinship of satire and comedy' depends for its effectiveness on 'whether the laughter is used to judge the occasion or the occasion used largely to achieve the laughter, ${ }^{\prime}{ }^{15}$ his argument stops short of elucidating the occasion, opting instead for more grandiose statements regarding the 'doubleness of its delighted welcome and amused demurrer, that together characterized his [Beaumont's] view of the theatre in general, and of the popular stage and its patrons in particular. ${ }^{2}{ }^{16}$

My contribution brings to the forefront the neglected subject of theatrical failure in early modern drama by returning our attention to the culture of playgoing at the Blackfriars and the culture of revels at the Inns of Court. This reconsideration of both institutions may help explain evidence pointing to the play's failure, as a 'new playwright's play', ${ }^{17}$ in terms of two possibly concomitant mistakes on Beaumont's part: first, his misguided 'retrofitting' of dramatic genre from the Inns of Court to the Blackfriars, and second, his misreading of the socio-economic dynamics of the Blackfriars audience, especially the Inns of Court students and the gentry, who were evidently loath to substitute their own game of judgment for the interactive one offered by the Citizen and his wife. The discombobulating effects of these parallel macro/micro transpositions, innovative as they are, are enhanced by an additional surprising novelty that Andrew Gurr points out: Blackfriars had no precedent for allowing the boy actors to address directly those watching the play while sitting on the stage (the gallants). ${ }^{18}$

The play was likely performed in June 1607, only a few years after Beaumont gave his Grammar Lecture at the Inner Temple (ca 1601-5), a revels burlesque in which he explicates the demographics of Inns of Court residents and their varying motivations for being there. ${ }^{19}$ If Beaumont was not a law student at the Inner Temple when he wrote Knight, then he had only recently given up his legal studies in order to begin writing plays for the theatres. As a budding playwright, Beaumont creates a performance condition in which the close proximity of citizen and elite tastes, personified by George and Nell's placement among the gallants sitting on the stage, commands the twoway game between the players and the audience. The play constructs this 
violence by setting the players' intention to perform The London Merchant alongside George and Nell's desire to see their apprentice Rafe perform in a pastoral romance. The violence of competing tastes that Beaumont stages here is itself an exhibition of the fierce social dynamics contained within the Blackfriars playhouse: the citizens' performance as intruders, violating what Bliss describes as the play's 'privileged space', ${ }^{20}$ invites members in each category of the audience to consider how they might be intruders of one another's rightful place of status, thereby drawing attention to the very status they might not necessarily possess otherwise, especially as one descends the social hierarchy.

Leggatt proposes how the play's multiple ploys are 'out of place at the Blackfriars' 21 - despite Zitner's prior claims for the play's structural alliance with its debut's venue - but with Beaumont's own institutional background in mind, we have the opportunity to give the dramaturgical choices in Knight a closer look in order to reconsider several questions about what determined the nature and composition of the Blackfriars' audiences: was it the theatre and its reputation, the playwright and his, or the company and its, and to what extent did the plays themselves contribute to the construction of their audiences?

This newly configured trajectory of Beaumont's metatheatrical Knight, his own institutional background at the Inns, his Grammar Lecture performance at Inner Temple revels, and other telling evidence regarding playgoing at the Blackfriars provide a unique vantage point from which to review this problematic area of early modern theatre history.

Beaumont's active participation in Christmas revels at Inner Temple clearly fostered his penchant for breaking the rules, albeit within the context of a highly codified institutional tradition designed to accentuate the fraternal bonds among the gentlemen in residence. The young, enterprising Beaumont apparently attempted to market his affiliation with the Inns for an audience of discriminating 'friends' by transferring a sanctioned yet transgressive model of revelling from the institution of Inner Temple commons to the Blackfriars. Revels at the Inns were designed to foster collegiality among men who were otherwise competing for advancement in London. Beaumont appears to have projected the community he inherited from the Inns - defined during revels by the occasional assimilation of men from varying social classes, and with individually divergent motives for being there, into a cohesive community — onto the Blackfriars' clientele, whose motives for attending a play were driven more by aggressive socio-economic 
competition. Basically, Beaumont seems to have mistaken the exception to the rule (Inns' revels) for the rule itself. By pursuing more explicitly the idea that Beaumont co-opted this notional 'new community' 22 from the Inns then failed to transpose it in the form of a play for the Blackfiars, we can surmise with greater perspective why the a priori understanding between Beaumont and the constituents of his audience that Knight manipulates so aggressively resulted in 'ingratitude' - if, of course, we take Burre's words at face value. But first, let's reconsider evidence suggesting the demographics of the audience to which he directed his nascent efforts as a playwright.

\section{'Certaine Observations' at the Blackfriars Theatre}

The Blackfriars playhouse functioned as a fashion-house of social competition - a place where London's privileged playgoers brandished their social status through the clothes they wore, the stories they told, and the seats they chose. During the early years of James's reign, the Blackfriars playhouse was a place in which London's wealthier playgoers, including law students, paid for the privilege of wasting time - an activity that was associated with the social elite. Attending a play at the theatre demonstrated one's engagement in a contest for prestige based on the appearance of having time and money to waste. The students' position in this playhouse was complex. At the Inns of Court, as Shapiro contends, they were part of the 'bottom of a hierarchical structure [of legal commons] to which [they were] ideologically or pragmatically committed'. ${ }^{23}$ By attending a performance at the Blackfriars, they entered an intimate and socially competitive environment composed of other privileged playgoers, who perhaps perceived this environment as a duplication of the exclusive social network centred at Whitehall. In the close company of patrons possessing varying amounts of economic, social, and cultural capital, the students encountered a range of people to meet, flatter, criticize, or perhaps even avoid.

The performance conditions of the Blackfriars created for the law students a kind of tension that both challenged and assuaged their concern for social status - a status that, at least for the more professionally-minded students, would eventually depend on their ability to apply their Inns education towards a profitable legal career. A seat in the Blackfriars afforded law students a chance to perform the status of London's elite. The students were low-ranking members of the legal community, however, so this advance was only temporary; the acrid and sarcastic tone of Henry Fitzgeoffrey's Satyres 
and Satyricall Epigrams: with Certaine Observations at the Black-fryars (1617), evidenced below, suggests that these young men came to the Blackfriars for the chance to offset their subordinate status within the strictly hierarchical structure at the Inns by critiquing venomously the pretentions of other playgoers and then publishing this vitriol as in-house gossip. ${ }^{24}$ Their continued patronage at Blackfriars depended significantly on the ability of the plays to appease their psychic need for a sense that they were part of London's social elite, for the other members of the audience could not necessarily satisfy this need. Fitzgeoffrey depicts an audience characterized by in-fighting and aggressive competition based on the appearance of commanding aesthetic taste and fashion.

Little is known about Henry Fitzgeoffrey other than that he was a student at Lincoln's Inn when he wrote his Satyres. In the Black Books Fitzgeoffrey's name is mentioned three times: once in relation to a financial dispute with one Mrs Wythins in January/February 1618, once concerning his chamber, which was 'disposed of for the payment of duties to the House' (25 June 1618), and once regarding his call to the bar on 14 June $1621 .{ }^{25}$ We can therefore assume that Fitzgeoffrey was a student at the time he wrote his observations of the gallants' row at the Blackfriars around 1617. His book was entered in the stationers' register on 9 October 1617. Consisting of 289 lines of unrhymed pentameter and divided into eleven parts of varying lengths, Fitzgeoffrey's Notes From Black-Fryers appears at the end of his collection.

The conditions of playgoing at the Blackfriars must have varied between 1617, when Fitzgeoffrey wrote his Notes, and 1607, when Beaumont's play was performed. Contemporary references regarding playgoing at the Blackfriars in the first decade of the seventeenth century (the 'Second Blackfriars'), however, exhibit similar kinds of 'observations' that Fitzgeoffrey makes one decade later. Jonson's verses for John Fletcher's pastoral tragicomedy The Faithful Shepherdess (ca 1608), also a failure at the Blackfriars, describe the Blackfriars audience as a 'wise and many-headed Bench ... Compos'd of Gamester, Captaine, Knight, Knight's man, / Lady, or Pusil', all 'rank'd in the darke.' ${ }^{26}$ The Induction to John Day's The Isle of Gulls (1606), which precipitated the loss of the company's royal association by the time Beaumont's play debuted, dramatizes the pickiness with which three gallants make their contradictory demands on the Blackfriars company - the first wants a satire, the second prefers a bawdy play, and the third orders 'bumbast Epithites'. ${ }^{27}$

Not even aware of what play is on that day, Fitzgeoffrey meets his friend 'Philemo' in one of the theatre's upper viewing boxes. ${ }^{28}$ Rather than smoking, 
they decide to 'deceive Time' by observing who else is attending the performance. ${ }^{29}$ What follows is a series of unflattering portraits of the patrons they see in the theatre; in each portrait the students criticize the dress, speech, demeanour, and behaviour of the playgoers. Fitzgeoffrey describes the Blackfriars as a world of unabashed conspicuous consumption. He wonders, for example, if a man whom he calls a 'world of fashions' - donning Spanish boots, Scottish spurs, a French-cut suit, and a Holland shirt, with 'His Haire like to your Moor's or Irish Lockes' — has just wandered in from a 'Countrey may-game'. ${ }^{30}$ After 'A Woman of the masculine Gender' proceeds to sit 'into the Gallants Row', Fitzgeoffrey notices that a 'plumed Dandebrat' appears to enjoy the ladies' attention because of his ability to dance 'skipping too and fro'. ${ }^{31}$ A 'Spruse Coxcombe, yon Affecting Asse', who 'never walkes without his Looking-glasse', is obsessed with the tidiness of his apparel. This 'witlesse Noddy' fasts on 'Oatmeale, Milke, and crums of Barly-bread' and avoids the taverns just so that he can fit into his tight, tailored suits. ${ }^{32}$

What is most interesting about Fitzgeoffrey's survey of the Blackfriars' clientele is its concluding description of the playwright John Webster (15801634), who collaborated with several playwrights associated with Philip Henslowe's company. By 1617, when he was thirty-seven, he had already written The White Devil (1612) and The Duchess of Malfi (ca 1614, Blackfriars) under his own name, so he was a known figure in the theatre business, though no mention of him appears in the Inns' records. Webster was engaged in a vicious war of words with a group of minor poets and playwrights at Lincoln's Inn including John Stephens, one of Fitzgeoffrey's friends. What begins as Fitzgeoffrey's string of personal insults and sexual puns turns into an assessment of Webster's reputation for convoluting the source material of his plays:

This is the Crittick that (of all the rest)

I'de not haue view mee, yet I feare him least,

Heer's not a word cursively I have Writ,

But hee'l Industriously examine it.

And in some 12. monthes hence (or there about)

Set in a shamefull sheete, my errors out.

But what care I it will be so obscure,

That none shall understand him (I am sure.) ${ }^{33}$

This final ad hominem attack against Webster illustrates the extent to which law students perceived themselves as judges of the entire theatrical enterprise, not just fellow competitors in the status game. Such evidence suggests that 
the law students would not be loath to turn against one of their own — even one such as Beaumont.

Fitzgeoffrey represents the playgoing law student as a critic of fashion, someone who prides himself on his ability to deconstruct the pretensions on display at the Blackfriars. More importantly, he makes it clear that his role as social critic is an integral part of his competitive time-wasting - criticism is his most adept weapon in the competition because it is the basis of commons culture at the Inns of Court. Nowhere is this culture characterized more precisely than in Thomas Overbury's depiction of 'A Fantastic Inns of Court Man' in his Characters (1614), illustrating how the law student uses his proclivity to criticize the stances of others as an expression of his own desired social position:

[He] laughs at every man whose band fits not well or that hath not a fair shoe-tie, and he is ashamed to be seen in any man's company that wears not his clothes well. His very essence he placeth in his outside, and his chief prayer is that his revenues may hold out for taffeta cloaks in the summer and velvet in the winter. ${ }^{34}$

Fitzgeoffrey's observations show us that the law students in the Blackfriars audience used their affiliation with the Inns as a badge of camaraderie that enabled them to pass judgment on those whom they perceived as competitors in the pursuit of the more valuable prestige associated with court culture. But James I had recently severed the connection between the company of boys at the Blackfriars and the court, so Beaumont constructs an elaborate smoke and mirrors act designed to appeal to everyone's sense of entitlement - even the boy actors, perhaps even his own - but in the end he apparently pleased nobody. To trace the roots of Beaumont's failure in 1607, and then to appreciate how the play's own structure precipitates it, we need to step back several years to when he was residing at Inner Temple Hall.

\section{Francis Beaumont's Grammar Lecture at Inner Temple Hall}

The third son of a justice of the common pleas, a member of an old distinguished Leicestershire family, and a matriculant of Broadgate Hall, Oxford, Francis Beaumont (ca 1584-1616) became a member of the Inner Temple (where his two brothers also resided) on 3 November 1600 around the age of sixteen, apparently because his father arranged for his admission. ${ }^{35}$ Soon after his admittance, he delivered his mock oration, the Grammar Lecture, 
at one of the Inn's Christmas revels (ca 1601-5) in Inner Temple Hall. This sudden involvement at the centre of revels suggests a precocious, ambitious, and dynamic character on Beaumont's part, one who seeks to step beyond his 'brethren'. Revels offered the perfect opportunity for someone like young Beaumont to do just that. During the holiday revels that took place in the hall, the furnishings that normally maintained a certain formal order - the tables, chairs, fireplace, and other partitions - were either rearranged or removed altogether. Students probably spoke on the benchers' side of the bar, a place normally off-limits to them; they crossed the line into the reader's place of privilege and authority. Revels created a festive environment in which the law students could freely fashion themselves as dominant agents in a cultural field of their own construction. The revels were, in fact, essential tools for the cultivation of their collective self-identity as future holders of positions in the royal court, in the professional legal sphere (in London or back home), or in other institutions. The cycles of legal education in commons provided a means for a student to gain professional success; the cycles of revels provided a means for a student to play the part of one who has achieved success. The effectiveness of revels, however, depended on the students' memory of the established order they had rearranged.

In this lecture, Beaumont describes three types of law students at the Inns: the 'young student', the 'reveller', and the 'plodder'. The young student is a naive 'soft imytating peece'; new to his Inn, he is just beginning to learn how to engage in mooting exercises and how to purchase a satin suit 'on trust'. ${ }^{36}$ Because he quickly runs into debt, he writes home for money - not to pay for books, but to see plays and puppet-shows. The reveller, with his pompous behaviour and eccentric clothes, resides at the Inns solely for the sake of fashion. The plodder, wearing a 'treble ruff and capacious cap', ${ }^{37}$ spends his time recording cases at Westminster Hall and reading legal yearbooks; he is the diligent reader whom Edward Coke claims will eventually enjoy a more complete understanding of the law than his less driven peers. ${ }^{38}$ Beaumont concentrates his oration on the four 'grammatical' elements that he claims an Inns student must master in order to enjoy the festivities of revels: orthography, etymology, syntax, and pronunciation. He explains how each of the three types of law students cultivates a distinctive legal grammar. By cultivating an impressive script (orthography), the young student, for example, can sign his bills with flair; etymology affords him the skills to gather funds for his expenditures (his 'compound'); with a command of syntax, he can 
efficiently spend this compound; his proper pronunciation enables him to match his eloquence with his habiliments. ${ }^{39}$

Beaumont engages his auditors in a mock lecture in the style of an imaginary reading on the elements of the various legal dispositions or styles of being a student at the Inns. Standing in the place of a reader in the Inner Temple Hall, he holds a place of authority in relation to his fellow students, and he explains what he sees in front of him. Beaumont is simultaneously one of these students and, in his role as the festive orator in the hall, also momentarily above his rank as student; he speaks in the powerful place normally occupied by the practicing barrister, and manipulates the anchored power dynamic that governs commons in order to legitimate a revised understanding of the students' relationship both to this dynamic and to the common law. The anchored state of the hall — its organization during term - marks a clear division between those who have access to the mysterious domain of legal knowledge through the medium of the spoken word (like Coke and other readers) and those who have not yet gained this power (the students). The conditions under which Beaumont delivered his lecture were characterized by the temporary dismantling of the hall's anchored state, which would not have been forgotten by the students who were enjoying the new possibilities offered by its transformation. In these conditions, Beaumont invites his auditors to join him in examining the different ways that they can use their association with the law as a form of social leverage.

Beaumont uses the form of a legal reading to explain how his fellow law students can either employ their membership in commons to learn how to transform legal capital into other forms, or to maintain it in its symbolic form (as William Fulbecke, in 1600, encouraged in A Direction or Preparative to the Study of the Lawe) by continuing the diligent study of the common law. ${ }^{40}$ Beaumont uses his usurped authority as a barrister to encourage his colleagues to interact with other cultural fields in London - to assess continuously the potential exchange value of their legal capital. This sort of sensibility is precisely what Fulbecke condemns, for in order to amass the legal capital necessary eventually to become a reader like the renowned barrister Edward Coke, the student should avoid moving into other fields entirely; he should remain exclusively in the confines of commons and experience its rigorous, sacrosanct rituals of cultural transmission. But this is the time of revels, so Beaumont upbraids Fulbecke by unmasking the various uses that his fellow students make of their leisure/reading time; he also uses his lecture as an attempt to undermine the self-deception typically associated with 
membership in Inner Temple. The plodding student's diligence will eventually lead him to the bar; this is a straightforward correlation, but one that would operate most effectively under controlled conditions.

Beaumont's point is that such conditions do not exist, and he sees his task as one of clarifying the place of the law student between the competing influence of London's luxury market and the rules of commons - rules that a character in Henry Parrot's The Mastive (1612) decides to follow only because he has nothing more exciting to do at the time:

Come; What shall's doe (qd. Ned) this afternoone?

That hath at Noddy neither lost nor wonne:

Theres not a Play (saith hee) worth looking on,

And Mistris Moll from Clarkenwell is gone.

Troth let's doo once what no man would conjecture,

Turne honest for an houre, and heare a Lecture. ${ }^{41}$

\section{Transitions}

Let's now consider the relationship between the circumstances of Beaumont's revels lecture at Inner Temple and the first performance(s) of Knight by the Children of the Revels at Blackfriars. The Inner Temple's revels presented finite and clearly licensed conditions for the inversions of social protocols and rankings; Beaumont's explicit use of these inversions in the play's allusions to carnivalistic boy/apprentice festivities would likely have been attractive to the boy players, who as little as a year before, when they were known as the Children of the Queen's Revels, had experienced their own real change in circumstances when James I issued a commission that had the effect of severing the choristers of the Chapel Royal from the company at the Blackfriars' because of plays offensive to the crown. ${ }^{42}$ Yet Beaumont's play indicates that the newly titled Children of the Revels were wearing 'periwigs' (1.471), symbolizing their once-held court connection, so they were apparently engaging in a form of symbolic defiance within their own fraternity. The entire Blackfriars audience may have been receiving mixed messages about its inclusion in this supposedly 'elite' environment, but of course this reception would depend on its collective knowledge of this royal severance. But the boy-prologue's announcement in the induction makes clear that his company has brought the play 'from [as in far away from] all that's near the court, from all that's great', which identifies the boy actors themselves as 
intruders by wearing (satirically?) the symbolic vestiges of a royal associative status they no longer technically hold. These boys were the leftovers from what was a company with a court connection, and they are now telling the gallants that the play they are about to watch is 'from all that's great'. The immediate invasion of George and Nell into the 'gallants' row' implicates the stool-sitters in this false encroachment, effectively upbraiding their elitism. Are the gallants being associated with citizens or the court?

The mixed messages would have been perhaps unsettling because they were not clearly contained by carnival traditions or established theatrical conventions; indeed the virtuosity that likely characterized both Beaumont's one-man show at Inner Temple and the boy actors' performance of his play at Blackfriars probably generated more divisive effects than Beaumont anticipated. Nevertheless, Nell's scripted conversation with the gallants emphasizes the sense that she has embraced their company:

By your leave, gentlemen all, I'm something troublesome; I'm a stranger here; I was ne'er at one of these plays, as they say, before; but I should have seen Jane Shore once; and my husband hath promised me, any time this twelvemonth, to carry me to The Bold Beauchamps, but in truth he did not. I pray you, bear with me. (53-9)

Beaumont's construction of this uncomfortably false intimacy, replete with an elaborate repartee of inside jokes designed perhaps to reaffirm the boys' own talents as professional players, implicates and interrogates the relative status of the audience clientele as 'judgers', rendering what Beaumont might have intended to be a collaborative inside joke into a forum of conflicted feelings of self worth. They are all paying patrons, so they are all involved in the farcical usurpation of judgment; the citizens offer the players money for their demands and thereby reduce the complex association between money and culture to a simple series of financial transactions, illustrating the extent to which they depend on the economy for their existence. By becoming part of the gallants' row, the grocers associate the gallants, and the lesser law students by association, with this dependency, thereby collapsing the imagined disassociation between the status of the Blackfriars as a fashion-house of culture and the economic realities on which this status depends. Clearly the response was a call to arms whereby the audience members, for a variety of reasons, violently reassumed their positions of judgment outside the Blackfriars by condemning the play. 
Beaumont's acculturation in legal commons, brief though it seems to have been, prompted him to devise a play using similar inversions of space (like revels), substitutions of roles and power (like revels), and themes of inclusion and exclusion (like revels) as a way to profit from his own friends. His audience, Leggatt argues, 'has paid real money to see an actor pay fake money, and to find the sight amusing. ${ }^{43}$ These transactions at the Blackfriars, however, are multivalent, unlike those of revels at the Inner Temple, where Beaumont could rely on the hegemonic culture among his upwardly mobile colleagues for the success of his game of interrogative role-playing as a way to communicate to them the purchase power of their legal education.

Leggatt, in my view, rightly argues that Knight 'demystifies theatre by presenting it as a cash transaction'; ${ }^{44}$ my analysis explores the question his argument begs: what aspects of 'theatre' at the Blackfriars does Beaumont demystify? Despite ignoring the lack of precedence in terms of violating the stool-sitting gentry's autonomy, Beaumont was very much following a recent pattern of dramaturgical retrofitting. Webster, a more experienced playwright than Beaumont at the time, even burlesques this phenomenon in his Induction to the third edition of John Marston's The Malcontent in 1604, a play first performed at Blackfriars but then appropriated by the Shakespeare's King's Men for performances at the Globe. ${ }^{45}$ The play's Induction consists of bantering among four of the King's Men playing themselves (including Burbage). Questioned by William Sly as to why the company is staging a Blackfriars play ('I wonder you would play it, another company having interest in it'), one of the well-known King's Men, [Henry] Cun[dell] (or Henry Condell), wittily responds, "Why not Malevole in folio with us as Jeronimo in Decimo sexto with them. They taught us a name for our play, wee call it One for another. ${ }^{46}$ The quip dramatizes a competitive retaliation: effectively, if the Children of the Chapel (who are small, like decimo-sexto sheets) can steal a play from the King's Men's repertory - 'Jeronimo' perhaps an abbreviation of The First Part of Jeronimo (a companion piece to The Spanish Tragedy), a reference to The Spanish Tragedy itself, or, as Paul Werstine proposes, another 'one of the King's Men's plays with Jeronimo in it' - then Shakespeare's men (folio sheets) can justifiably co-opt Marston's evil character, Malevole. ${ }^{47}$ Werstine shares E.K. Chambers's doubts as to whether this dramatized retaliation was based on an actual theft of plays, and I tend to agree, but whether the thievery was real or concocted is not the most pressing point. ${ }^{48}$ The vignette's appearance in the first place - if not on stage than at least certainly in print — suggests that the discourse of retaliation 
and proprietorship was for the most part a clever and dramatic marketing strategy designed to increase sales of printed editions. ${ }^{49}$

While Beaumont's play was not a transposition between theatres as such, it was, I argue, the result of a more naïve, yet complex attempt to write for an audience he presumed he knew well, an audience that would guarantee the play's automatic appeal. As Zitner proposes, the play's 'ebullience comes in large measure from ... [Beaumont's] self-discovery of talent and the discovery of the theatre. ${ }^{50}$ If he could entertain his colleagues at the Inns of Court successfully at Christmas revels, why not use the same strategies at the Blackfriars and also make some money at it? To pursue this line of questioning, we must return to Leggatt's argument, which takes for granted Walter Burre's condemnation of Beaumont's audience as lacking 'judgment' and 'understanding' by claiming that '[n]o judgment is in fact the underlying problem of the Blackfriars audience', which rejected both The Knight of the Burning Pestle and, one year later, The Faithful Shepherdess. ${ }^{51}$ Burre's letter appears to me as a desperate ploy to market the printed edition by flattering Keysar's taste in spite of the play's failure, so I contend that the opposite situation is present: too much judgment was taking place. Beaumont's 'mischievous interplay' 52 disoriented radically the hierarchical social configuration the Blackfriars audience expected, so the lack of understanding seems to be on Beaumont's part, not that of his audience. Leggatt's recent argument that the play failed because the audience insisted 'brazenly and excessively, on its rights' 53 presumes a unified audience that thinks and responds collectively, but evidence examined above shows otherwise.

Even though Beaumont was making 'friends' with his fellow students by using the traditional form of revels to invert momentarily their subservience, this strategy apparently did not 'translate' well in a commercial institution like the Blackfriars - even though Beaumont was likely aware that the Inns students constituted a good percentage of the paying audience there. Knight's clever strategies likely irritated the gallants by stealing their critical thunder and associating them with lowbrow citizen tastes. More importantly, it unwittingly sent conflicting messages to the Inns of Court fashion-obsessed playgoers regarding their stake in the game of judgment. In one sense, Beaumont's intrusive metatheatrical postures collaborated with the students by imitating their jealous criticism of the gallants, thereby perhaps encouraging their disdain, yet it possibly also fuelled their own insecurities by 'cooperating' too closely with the gallants, thereby ostracizing the students even more than they already were. 
Perhaps Beaumont presumed that the technique of deconstructing the economic value of legal study in the marketplace as entertainment during revels in Inner Temple Hall (where time theoretically buys money) would have the same effect at the Blackfriars (where money effectively buys time). These clever inversions in his experimental play make the varying pretensions of the audience - from the gallants who profess judgments of taste, to the Inns students who feel entitled to critique these judgments - too explicit by accentuating and then appropriating their critical acumen, thereby cheapening the value of their purchase. Paying to attend a performance at the Blackfriars gave patrons an enhanced sense of entitlement to use the plays they were seeing as vehicles for exhibiting and competing for superiority through critical judgment. Beaumont's play, however, by absorbing this entitlement, leaves behind for its audience an aesthetic too closely tied to money (their admission fee) to uphold the distance necessary for the social competition game in the theatre to continue.

\section{Conclusions}

Beaumont's failure suggests that economic competition among theatres was so fierce that it urged playwrights not only to retrofit plays across venues but also to write with an attempt to exploit a sense of 'insider' institutional knowledge as a proactive marketing strategy — even at the ostensible expense of the play's own reputation. The fact that these strategies sometimes backfired so violently suggests that playgoers were quick to condemn playwrights' attempts at such conspicuous efficiency. Beaumont's play heightens this tension uniquely by appropriating the playgoers' perceived entitlement to criticism (of the play of course, but especially of one another as fellow critics) for dramatic purposes. This 'staging of thwarted reception' ${ }^{54}$ transfers the forum of discrimination from the audience to the stage, leaving the paying patrons disenfranchised from part of the experience of social one-upmanship for which they have paid.

In Inner Temple Hall, the efficacy of Beaumont's lecture during revels was based, as Peter Goodrich has researched extensively, on an institutionally defined culture of memory that promises delayed gratification - a promise that revels, as a sanctioned intrusion, enables Beaumont to undermine momentarily. During the performance of his play at the Blackfriars, however, this performance of intrusion, Leggatt argues, has real and immediate effects based ironically on the 'impossibilities [of] instant gratification, illusions that 
become realities'55 that are not sanctioned by the paying patrons. While revels at the Inns enable Beaumont and his peers to contemplate upward mobility, his use of this same form as entertainment at the Blackfriars enacts downward mobility despite its apparent intentions otherwise. This effect is the basis of Beaumont's misunderstanding: his artifice usurps the expected roles of judgment for which the patrons are paying to enjoy. The boys playing grocers George and Nell effectively take over the gallants' rights as judgers of the play, yet their aesthetic intolerance is grounded on plebian tastes, so by mocking (through imitation) citizen tastes as intruding gallants, they associate directly the status of both by collapsing the aesthetic distance between them. During the third intermission, for example, Nell indicates her inability to appreciate a dancing boy's artistry, then further exemplifies her bad form by throwing money at him so he can buy new laces for his shoes:

NELL Begin, brother, Now 'a capers, sweetheart. - Now a turn o' the toe, and then tumble. Cannot you tumble, youth?

Boy No, indeed, forsooth.

NELL Nor eat fire?

воY Neither.

NELL Why, then, I thank you heartily: there's two-pence to buy you points withal. (3.614-21)

The play includes another financial exchange of this kind. In the induction, George offers the boy-prologue two shillings so that he might hire the 'waits of Southwark' (118-20), a city band that George would prefer to hear far more than the musicians at the Blackfriars. At other points in the play, George and Nell flaunt their crude reception of the play. Nell offers Rafe candy (1.71-4); George gives him money as well, once to pay the twelve shillings Rafe owes to avoid arrest (3.183) and once to purchase something nice that will grace the home of the king of Cracovia (4.112-14). The play's epilogue mocks these close proximities of competing tastes, for Nell implies that the gallants' luxurious expenditures on wine and tobacco are as subtle as their ability to mask their opinions:

GEORGE Come, Nell, shall we go? The play's done.

NELL Nay, by my faith, George. I have more manners than so; I'll speak to these gentlemen first.-I thank you all gentlemen, for your patience and countenance to Rafe, a poor fatherless child; and if I might see you at my house, it should go hard but I would have a pottle of wine 
and a pipe of tobacco for you; for truly I hope you do like the youth, but I would be glad to know the truth.

The gallants were probably offended by their forced inclusion in the lowbrow antics, but the reaction of Beaumont's own peers to these antics also interests me. Perhaps the law students were offended by having their resentments burlesqued in front of them in such crass fashion by the leftover boys, or perhaps they joined in to stir the pot. By mocking gallants' tastes in this associative fashion, the boys echo exactly the sentiments felt by the law students in attendance that Fitzgeoffrey voices. The effects of this duplicity could be manifold: it might make the gallants feel cornered by provoking the students' resentments, it might embarrass the students by exploiting sentiments against those they might be ostensibly trying to impress, or it unwittingly might make them feel excluded from the satiric façade. If the students' roles as liminal critics have been co-opted by 'grocers', where does this co-opting leave them? What has their purchase afforded them — roles as mere auditors? By allowing boy actors to critique the gallants' aesthetic disposition by performing the intrusion of citizen tastes into their circle, might Beaumont have left his peers feeling as if their own critical acumen was being associated with the lowbrow musical tastes of George and Nell and their unfamiliarity with the practices, protocols, and vestments of the Blackfriars?:

NELL The fiddlers go again, husband.

GEORGE Ay, Nell, but this is scurvy music. I gave the whorson gallowsmoney, and I think he has not got me the waits of Southwark. If I hear 'em not anon, I'll twinge him by the ears. - You musicians, play 'Baloo'.

NELL No, good George, let's ha' 'Lachrymae'.

Patrons purchase seats of judgment - of the play, of the author, of one another. Beaumont exposes, as he does in his lecture, the different sources and objects of amusement this money was intended to allow its audience to judge in a delineated fashion. Gallants, law students, and citizens alike, as participants in this exposure, are therefore forced to witness themselves as having purchased themselves as their own collective commodity but without the collaborative understanding that would affirm this symbolic role-play as ironic. Because paying patrons from broader walks of civic life compose his theatre audience, the codes of conduct are different, and by breaking these rules of what is not a game, Beaumont's conflation of the two different audience cultures at the Inns of Court and Blackfriars converts the fashion of 
friendship into the kind of vindictive slander that anticipates Fitzgeoffrey's Observations.

\section{Notes}

1 John Webster, The White Devil (London, 1612; sтc 25178), A2r.

2 Francis Beaumont, The Knight of the Burning Pestle (London, 1613; sтc 1674).

3 Douglas A. Brooks, From Playhouse to Printing House: Drama and Authorship in Early Modern England (Cambridge, 2000), 52.

4 Ibid.

5 Alexander Leggatt, 'The Audience as Patron: The Knight of the Burning Pestle', Paul Whitfield White and Suzanne R. Westfall (eds), Shakespeare and Theatrical Patronage in Early Modern England (Cambridge, 2002), 312; Lee Bliss, Francis Beaumont (Boston, 1987), 36-7.

6 Leggatt, 'The Audience as Patron', 300.

7 Andrew Gurr, The Shakespearian Playing Companies (Oxford, 1996), 102; Michael Shapiro, Children of the Revels: The Boy Companies of Shakespeare's Time and Their Plays (New York, 1977), 76-7.

8 Ronald F. Miller, 'Dramatic Form and Dramatic Imagination in Beaumont's Knight of the Burning Pestle', English Literary Renaissance 8 (1978), 68.

9 Zachary Lesser, 'Walter Burre's The Knight of the Burning Pestle', English Literary Renaissance 29 (1999), 21-43.

10 Sheldon Zitner (ed.), The Knight of the Burning Pestle (Manchester, 1984), 9. All future references to act, scene, and line numbers from this play cite this edition and appear parenthetically in the essay.

11 Ibid, 16.

12 Ibid, 14.

13 Ibid, 32.

14 Ibid, 28.

15 Ibid, 32.

16 Ibid, 38.

17 Ibid, 39.

18 Andrew Gurr, discussion with the author, March 2008.

19 Charles Mills Gayley, Beaumont, the Dramatist: A Portrait (New York, 1914), 31314.

20 Bliss, Francis Beaumont, 44.

21 Leggatt, 'The Audience as Patron', 305. 
22 Zitner, Knight, 28.

23 Shapiro, Children of the Revels, 52.

24 Henry Fitzgeoffrey, Satyres: and Satyricall Epigrams: with Certaine Observations at the Black-fryers (London, 1617: sTC 10945).

25 The Records of the Honourable Society of Lincoln's Inn: The Black Books, ed. W.P. Baildon and R.F. Roxburgh (London, 1897), 2.199-200; 206; 222.

26 John Fletcher, The Faithful Shepherdess (London, 1629; sTC 11069), A3r.

27 John Day, The Isle of Gulls (London, 1606; sтC 6413), A2v, A3r .

28 Fitzgeoffrey, Satyres, E7r.

29 Ibid, E7v.

30 Ibid, F1v.

31 Ibid, F2r.

32 Ibid, F4v-F5r.

33 Ibid, F7r.

34 Thomas Overbury, A Wife... Whereunto Are Added Many Witty Characters and Conceited News, Written by Himself and Other Learned Gentlemen His Friends (London, 1616; sтC 18910), H2r.

35 A Calendar of the Inner Temple Records, Inner Temple, 2 vols, ed. F.A. Inderwick (London, 1896), 1.435.

36 Mark Eccles, 'Francis Beaumont's Grammar Lecture', The Review of English Studies 16.64 (Oct. 1940), 406.

37 Ibid, 414.

38 Richard Helgerson, Forms of Nationhood: The Elizabethan Writing of England (Chicago, 1992), 100.

39 Eccles, 'Grammar Lecture', 408.

40 William Fulbecke, A Direction or Preparative to the Study of the Lawe (London, 1600).

41 Henry Parrot, The Mastive or Young Whelpe of the Olde Dogge, Epigrams and Satires (London, 1615; sTC 19333), D2r.

42 Leggatt, 'The Audience as Patron', 297.

43 Ibid, 302.

44 Ibid, 300.

45 John Marston, The Malcontent (London, 1604; sTC 17481).

46 Ibid, A4r

47 Paul Werstine, 'Narratives About Printed Shakespeare Texts: "Foul Papers" and "Bad Quartos", Russ McDonald (ed.), Shakespeare: An Anthology of Criticism and Theory 1945-2000 (Oxford, 2003), 336.

48 E.K. Chambers, The Elizabethan Stage, 4 vols (Oxford, 1923), 3.432. 
i30 Brent E. WhitTed

49 For fascinating insight into these aspects of the epistles, see Lesser, 'Walter Burre's The Knight', 21-43, and John Pendergast, "Comedies for Commodities": Genre and Early Modern Dramatic Epistles', English Literary Renaissance 38.3 (2008), 483-505.

50 Zitner, Knight, 39.

51 Leggatt, 'The Audience as Patron', 314.

52 Ibid, 310.

53 Ibid, 296.

54 Zitner, Knight, 28.

55 Leggatt, 'The Audience as Patron', 311, my emphasis. 